\title{
DAMPAK PERILAKU KONSUMEN TERHADAP PENGGUNAAN AKSES SITUS ON-LINE SHOP (STUDI KASUS PADA MAHASISWA DI UNIVERSITAS PANCASAKTI TEGAL)
}

\author{
Agnes Dwita Susilawati ${ }^{1}$, Dewi Apriani Fr ${ }^{2}$ \\ Email : agnesdwita@gmail.com \\ Dosen Fakultas Ekonomi Universitas Pancasakti Tegal
}

\begin{abstract}
The development of information technology has touched various joints of human life, especially the development of the internet. The development of the internet forms a new world where every individual has the right and ability to interact with other individuals indefinitely. The objectives of the research are (1) The influence of service quality on consumer satisfaction in accessing online shop website, (2) To know the influence of attitude and trust toward online shop shop user and (3) Influence of satisfaction to consumer loyalty online shop. Data analysis method used is included in the category of quantitative data analysis is a data analysis using statistical instruments. Statistical instruments used are Chi Square Test and performed using SPSS (Statistical Package For Social Science) software. The results of model fit testing showed that the four factors (cultural, economic, social and ethical) that have the most contigency coefficient on consumer behavior in accessing online shop site are Social variables. This means showing a group of people or individuals having a relationship between consumers with each other in choosing products through an online shop site and building good communication in choosing products and knowing the risks faced when buying products through online shop site.
\end{abstract}

Keywords: Consumer Behavior, Use of On-Line Website Access Shop

\begin{abstract}
ABSTRAK
Pola konsumsi yang begitu tinggi untuk membeli suatu barang atau menjual barang melalui situs tersebut. Tujuan penelitian adalah (1) Pengaruh kualitas layanan terhadap kepuasan konsumen dalam mengakses situs online shop,(2) Untuk mengetahui pengaruh sikap dan kepercayaan terhadap pengguna situs akses online shop dan (3) Pengaruh kepuasan terhadap loyalitas konsumen online shop. Penelitian menggunakan Metode analisis data yang digunakan adalah termasuk dalam kategori analisis data kuantitatif yaitu suatu analisis data dengan menggunakan instrumen-instrumen statistik. Instrumen Statistik yang digunakan adalah Uji Chi Square dan dilakukan dengan menggunakan software SPSS. Hasil pengujian kecocokan model menunjukan dari ke empat faktor tersebut (kebudayaan, ekonomi, sosial dan etika) memiliki koefisien kontigensi paling besar terhadap perilaku konsumen dalam mengakses situs online shop adalah variabel sosial.
\end{abstract}

Kata Kunci: Perilaku Konsumen, On-Line Shop, 


\section{PENDAHULUAN}

Perkembangan teknologi informasi (internet) telah menyentuh berbagai sendi kehidupan manusia khususnya perkembangan internet. Dari seluruh aspek kehidupan manusia terkena dampak keberadaan internet, sektor bisnis dalam kondisi ini yang paling terasa. Internet adalah sistem informasi global berbasis komputer. Untuk mengakses internet kita hanya membutuhkan seperangkat modem, saluran telepon, atau menggunakan wireless internet.

Dalam dunia bisnis, banyak perusahaan dan organisasi kini telah menerapkan teknologi berbasis internet, dari sistem komunikasi, metode pembayaran bahkan sampai penawaran produk. Hal ini berkaitan dengan semakin tingginya kebutuhan informasi akan perkembangan ilmu pengetahuan dan teknologi terutama dalam hal penjualan dan pembelian produk barang / jasa melalui teknologi informasi berupa sebuah internet.

Pola konsumsi masyarakat untuk membeli suatu barang atau menjual barang melalui situs akses online shop merupakan bentuk perubahan yang disajikan oleh media internet. Sehingga dapat dikategorikan inovasi berbelanja. Mereka berpikir membeli produk atau menjual produk pada situs tersebut merupakan hal yang dianggap sangat menarik, karena mudah dalam hal semua pelayanannya. Selain itu beranggapan bahwa berbelanja maupun berjualan itu sudah mengikuti perkembangan teknologi sekarang dan dapat di terima oleh lingkungan sekitar. Dengan memanfaatkan multimedia waktu sangat cepat diperoleh data berbentuk suara, gambar, dan teks. Situs on-line shop dapat di akses melalui alat komunikasi seperti Blackberry Messenger, Android, dan Sosial Media dimana fungsinya untuk memudahkan dalam mengaksesnya. Dengan demikian semakin maraknya situs on-line shop di kalangan masyarakat semakin diberi kemudahan untuk melakukan pembelian maupun penjualan secara online.

Dari fenomena yang didapatkan oleh peneliti melalui observasi dan wawancara terhadap perwakilan Mahasiswa maupun karyawan kebiasaan mengakses situs online shop menjadi 
prioritas yang utama karena dengan melakukan transaksi pembelian atau belanja produk pada situs tersebut dimudahkan dalam hal transaksi pembayaran dengan tidak sadar bahwa bisa menghabiskan uang yang tidak pernah terduga. Hal ini disebabkan mengikuti tren jaman sekarang dan lingkungan serta semakin canggihnya kemajuan dari teknologi informasi untuk mengakses situs online shop.

Online Shop atau belanja via internet adalah salah suatu proses pembelian barang/jasa dari mereka yang menjual melaui media internet (Alfatris 2014). Sejak kehadiran media internet banyak pedagang telah berusaha membuat toko online dan menjual produknya kepada mereka yang sering menjelajah dunia internet. Para pelanggan dapat mengunjungi atau mengakses online shop dengan mudah dan nyaman dimana dapat di akses di rumah, kantor atau di manapun selama terhubung dengan jaringan internet. Dengan adanya perilaku online shop bahwa mahasiswa ingin menunjukkan kepada masyarakat bahwa mereka bisa di antara kelompoknya dengan gaya hidup yang sama. Perilaku on line shop yang terus menerus ini, akan memberi konstribusi kepada masyarakat, berperilaku konsumtif dengan memenuhi kebutuhan secara berlebihan atas dasar tertarik dengan produk yang ditawarkan atau bahkan dari teman kuliahnya juag membeli barang melalui online shop. Bahkan di kalangan peserta didik (mahasiswa) membeli produk pada online shop sudah merambah. Alasannya dikarenakan sangat mudah tidak perlu pergi keluar rumah atau mengunjungi toko tersebut dan pembayarannnya pun bisa di lakukan memalui internet banking. Perilaku konsumen menurut Kotler dan Keller (2008:214) adalah studi bagaiaman individu, kelompok dan organisasi memilih, membeli menggunakan dan menempatkan barang, jasa, ide dan pengalaman untuk memuaskan keinginan dan kebutuhan mereka. Schiffman dan Kanuk (2008:6) adalah Perilaku konsumen menggambarkan cara individu mengambil keputusan untuk memanfaatkan sumber daya mereka yang tersedia (waktu, uang, usaha) guna membeli barang-barang yang berhubungan dengan konsumsi. Dua hal penting dari pendapat tersebut 
di atas, yaitu (1) sebagai kegiatan fisik, dan (2) sebagai proses pengambilan keputusan Tujuan penelitian adalah (1) Pengaruh kualitas layanan terhadap terhadap pengguna situs akses online shop dan Pengaruh kepuasan terhadap loyalitas konsumen online shop.

Online Shop atau belanja via internet adalah salah suatu proses pembelian barang/jasa dari mereka yang menjual melaui media internet (Alfatris 2014). Sejak kehadiran media internet banyak pedagang telah berusaha membuat toko online dan menjual produknya kepada mereka yang sering menjelajah dunia internet. Para pelanggan dapat mengunjungi atau mengakses online shop dengan mudah dan nyaman dimana dapat di akses di rumah, kantor atau di manapun selama terhubung dengan jaringan internet. Dengan adanya perilaku online shop bahwa mahasiswa ingin menunjukkan kepada masyarakat bahwa mereka bisa di antara kelompoknya dengan gaya hidup yang sama.

Perilaku on line shop yang terus menerus ini akan mengakibatkan mahasiswa berperilaku konsumtif dengan memenuhi kebutuhan secara ber- kepuasan konsumen dalam mengakses situs online shop, (2) Untuk mengetahui pengaruh sikap dan kepercayaan

lebihan atas dasar tertarik dengan produk yang ditawarkan atau bahkan dari teman kuliahnya juag membeli barang melalui online shop. Bahkan alasan mahasiswa membeli produk pada online shop karena mudah tidak perlu pergi keluar rumah atau mengunjungi toko tersebut dan pembayarannnya pun bisa di lakukan memalui internet banking atau cukup mentrasfer.

Manfaat yang ingin dicapai penulis dalam penelitian ini adalah (1) Menerapkan teori dan informasi tambahan mengenai kualitas pelayanan, kepuasan konsumen dan loyalitas konsumen, (2) Sebagai referensi bagi peneliti lain yang akan melakukan penelitian dengan topik sejenis di masa yang akan datang, (3) Sebagai bahan masukan terhadap pembuat situs online shop supaya lebih berorientasi pada faktor-faktor yang mempengaruhi perilaku belanja konsumen, (4) Sebagai referensi bagi peneliti lain yang akan melakukan penelitian dengan topik sejenis di masa yang akan datang 
dan (5) Bermanfaat bagi masyarakat mengenai pengaruh sikap, norma, dan kontrol perilaku dalam berbelanja melalui media online shop.

\section{TINJAUAN PUSTAKA DAN HIPOTESIS}

Perilaku konsumen pada hakikatnya untuk memahami mengapa konsumen melakukan dan apa yang mereka lakukan. Konsumen memiliki keragaman yang menarik untuk di pelajari karena meliputi seluruh individu dari berbagai usia, latar belakang budaya, pendidikan, dan keadaan sosial ekonomi lainnya. Oleh karena itu sangatlah penting untuk mempelajari bagaimana konsumen berperilaku dan faktor-faktor apa saja yang mempengaruhi perilaku tersebut.

Selanjutnya ada baiknya kita melihat beberapa pengertian Perilaku Konsumen sebagai berikut: Perilaku Konsumen (consumer behavior) adalah kegiatan-kegiatan individu yang secara langsung terlibat dalam mendapatkan dan mempergunakan barang-barang dana jasa-jasa, termasuk didalamnya proses pengambilan keputusan pada persiapan dan penentuan kegiatan- kegiatan tersebut ( James F Engel dalam Basu Swastha dan Hani Handoko, 1987:9), (2) Perilaku Konsumen adalah ilmu yang mempelajari tingkah laku konsumen dalam arti kelakuan tindakannya untuk membeli suatu barang atau jasa tertentu (Alex S Niti Samito, 1989:9), (3) Perilaku konsumen adalah studi bagaiaman individu, kelompok dan organisasi memilih, membeli, menggunakan dan menempatkan barang, jasa, ide atau pengalaman untuk memuaskan keinginan dan kebutuhan (Kotler dan Keller, 2008:214), (4) Perilaku konsumen menggambarkan cara individu mengambil keputusan untuk memanfaatkan sumber daya mereka yang tersedia (waktu, uang, usaha) guna membeli barang-barang yang berhubungan dengan kon-sumsi (Schiffman dan Kanuk,2008:6)

Faktor yang mempengaruhi perilaku membeli menurut Kotler (2003:183-206 dan Suhari 2008) terdiri dari: Kebudayaan yang terdiri dari budaya, sub budaya dan kelas sosial yang terdiri dari kelompok acuan, keluarga, peran dan status. Personal yang terdiri dari usia dan 
siklus hidup, pekerjaan keadaan ekonomi, gaya hidup, kepribadian dan konsep diri. Psikologi yang terdiri dari motivasi, persepsi, proses belajar, kepercayaan dan sikap.

Perilaku konsumen akan menentukan proses pengambilan keputusan dalam pembelian mereka. Proses pengambilan keputusan tersebut merupakan suatu pendekatan penyelesaian masalah yang terdiri atas 5 tahap yaitu (Kotler, 2008:234) : (1) Pengenalan Masalah; (2) Pencarian Informasi; (3) Evaluasi Alternatif; (4) Keputusan Pembelian dan (5) Perilaku Setelah Membeli.

Toko online (online Shop) adalah kegiatan jual beli atau perdagangan elektronik yang memungkinkan konsumen untuk dapat langsung membeli barang atau jasa dari penjual melalui media internet menggunakan sebuah web browser untuk mencari, menawar atau memebeli produk dengan niat membeli dan mendapatkan produk tersebut (en.wikipedia.org). Online shopping memungkinkan kedua pembeli dan penjual untuk tidak bertatap muka secara langsung, sehingga hal ini memungkinkan penjual untuk men- dapat pembeli dari luar negeri atau internasional. Kegiatan tersebut merupakan bentuk komunikasi baru yang tidak memerlukan komunikasi tatap muka secara langsung, melainkan dapat dilakukan secara terpisah dari dan ke seluruh penjuru dunia melalui media komputer, notebook, ataupun handphone yang tersambung dengan layanan akses Internet. Pertama kali bermula pada tahun 1990 Tim Berners-Lee menciptakan browser web World Wide Web yang mengubah jaringan telekomunikasi akademik menjadi sistem komunikasi untuk semua orang setiap hari secara mengglobal yang dikenal dengan nama Internet. Pada awalnya penggunaan Internet bertujuan komersial dilarang dengan keras, ini dikarenakan adanya larangan commercial network traffic oleh National Science Foundation's (NSFNET) yang merupakan backbone Internet. tahun 1991 NSF menghapus larangan untuk tujuan komersial dan saat itulah membuka jalan bagi electronic commerce (e-commerce). Hanya saja, tidak semua kebijakan mengenai komersial dicabut. Baru pada tanggal 30 April 1995, batasan 
komersial yang paling terakhir dicabut. Jika menelusuri sejarah, maka Pizza Hut-lah yang menjadi perusahaan paling pertama mendirikan toko online. Mereka menyediakan fasilitas pemesanan online atau pengiriman ke rumah untuk testing pada tahun 1994 di Santa Cruz, California. Pada tahun 2007 seluruh daerah sudah mendapatkan opsi dalam sistemnya. Pada akhir tahun 2000, banyak perusahaan Eropa dan Amerika menyediakan fasilitas pelayanan melalui World Wide Web. Semenjak saat itulah, orang mulai mengasosiasikan istilah "ecommerce" sebagai kemampuan untuk membeli berbagai produk melalui Internet. Istilah ecommerce waktu zaman sebelumnya lebih mengarah ke transaksi secara online/elektronik. Berlanjut pada tahun 1995, Amazon muncul sebagai toko buku online. Belakangan perusahan tersebut menyadari barang dagangan lainnya juga memiliki permintaan yang tinggi, sehingga pada akhirnya mengadakan perluasan dengan menjual berbagai komoditas.

Belanja online di Indonesia untuk pembelian suatu barang menga- lami perkembangan yang cukup pesat. Mulai dari situs yang menjual handphone, gitar, butik, toko buku, makanan, bahkan hingga ke alat elektronik pun mulai dirambah oleh layanan belanja online shop. Beberapa media belanja online yaitu : (1) Blog; (2) Situs Web; dan (3) Situs Jejaring Sosial.

Kelebihan Bisnis Online Shop yang mulai menjamur ini di anggap menjanjikan bagi beberapa pihak. Keuntungan yang di hasilkan juga tak patut di pertanyakan lagi. Tak perlu bermodal 'toko' secara fisik untuk mempromosikan barang yang di jual, kita dapat mempromosikan lewat gambar yang selanjutnya di pajang di website atau 'toko virtual' milik kita melalui internet.

Kekurangan Online Shop sebagian masyarakat yg masih takut untuk melakukan belanja secara online. Sebagian orang takut untuk membeli barang secara online karena menganggap barang yang hanya di lihat secara gambar masih tidak cukup sebelum dilihatnya, serta diraba nya secara langsung. Sebagian lagi beranggapan, jika hanya melihat 
gambar, dan mengira wujudnya saja, bisa jadi barang yang di beli tidak sesuai dengan ekspektasi atau bayangan kita. Atau lebih gamblangnya, mereka takut merasa kecewa atau di kecewakan dengan barang yang di dapatkannya setelah melakukan transfer sejumlah uang tertentu Karena transaksi sebagian besar online shop, dilakukan dengan cara mengirimkan sejumlah uang tertentu terlebih dulu kepada toko online, baru barang di kirim. Walaupun masih banyak orang yang masih ragu dengan berbelanja online (online shop), tetapi karena alasan kenyamanan, mereka yang memutuskan untuk mencoba belanja online bertambah sangat cepat.

Hasil studi pendahuluan menunjukkan bahwa terdapat beberapa permasalahan yang ditimbulkan oleh perilaku konsumen khususnya mahasiswa di Universitas Pancasakti Tegal dalam melakukan pembelian melalui akses situs online shop.

Berdasarkan uraian di atas maka, pertanyaan penelitian adalah: " $\mathrm{Ba}$ gaimana mengetahui dinamika perilaku konsumen terhadap pembelian produk melalui akses situs online shop di kalangan mahasiswa Universitas Pancasakti ?" Kualitas pelayanan, kepuasan konsumen dan loyalitas konsumen. Sangat diperlukan sebagai bahan masukan terhadap pembuat situs online shop, hal ini agar berorientasi pada faktor-faktor yang mempengaruhi perilaku belanja konsumen yang memanfaatkan situs online. Mengacu pada permasalah di atas, maka hipotesis yang diuji sebagai berikut: Ha: ada pengaruh perilaku konsumen terhadap penggunaan situs online shop pada mahasiswa UPS Tegal.

Temuan tentang faktor yang mempengaruhi Perilaku konsumen terhadap penggunaan situs online shop dituangkan dalam model empiris kerangka pemikiran mengenai "Dampak Perilaku Konsumen Terhadap Penggunaan Situs Online Shop pada Mahasiswa Universitas Pancasakti Tegal”.

\section{Gambar 1 Kerangka Penelitian}

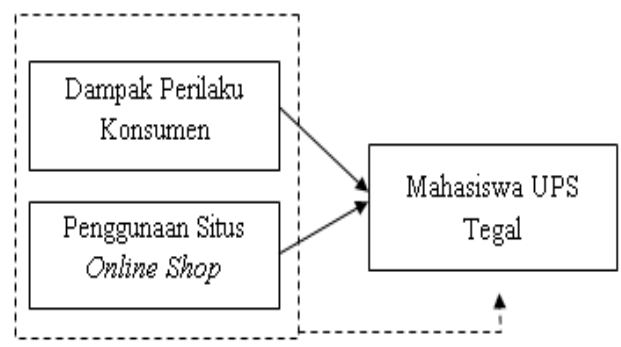




\section{METODE PENELITIAN}

Metode yang digunakan dalam penelitian ini adalah metode deskriftif analisis, khususnya penelitian kasus. Hasil yang diperoleh merupakan gambaran nyata dalam masyarakat (lingkungan tertentu) dari masalah yang diteliti Penelitian dilaksanakan di Kampus Universitas Pancasakti Tegal. Teknik Pengumpulan data menggunakan : Angket (Kuesioner), Observasi, Penetapan Populasi dan Sampel. Populasi penelitian adalah seluruh Mahasiswa Fakultas Ekonomi dan FKIP yang terdiri dari Program studi Manajemen dan Pendidikan Ekonomi. Dengan metode deskriftif analisis, khususnya penelitian kasus. Sampel diambil dengan menggunakan teknik accidental non random sampling, yaitu teknik penentuan sampel berdasarkan kebetulan yaitu siapa saja yang secara kebetulan bertemu dengan peneliti dapat digunakan sebagai sampel ( Sugiyono, 2003:60 ). Pada penelitian ini mengambil sampel sebanyak 100 mahasiswa. Hasil yang diperoleh merupakan gambaran nyata dalam masyarakat (lingkungan tertentu) dari masalah yang diteliti.
Metode analisis data yang digunakan adalah termasuk dalam kategori analisis data kuantitatif yaitu suatu analisis data dengan menggunakan instrumen-instrumen statistik. Instrumen Statistik yang digunakan adalah Uji Chi Square dan dilakukan dengan menggunakan software SPSS (Statistical Package For Social Science).Uji Chi Square untuk menguji dependensi hubungan antara penggunaan situs online shop dengan perilaku konsumen.Rumus yang digunakan (Sugiyono, 2003:104):

$$
x^{2}=\sum \frac{(f o-f h)}{f h}
$$

Indikator kebudayaan berdasarkan penelitian dari kebiasaan, cara memilih, jenis produk. Indikator ekonomi terdiri dari factor kebutuhan, produk yang efisien dan efektif serta pemilihan produk. Indikator sosial, terdiri dari membangun hubungan komunikasi konsumen dalam memilih dan membeli produk on line, toleransi menghadapi resiko memilih dan membeli produk. Indikator etika terdiri dari norma konsumen dalam memilih dan membeli produk, kebiasaan 
konsumen dalam memutuskan pembelian produk. Indikator keputusan Pembelian produk berdasarkan pendapatan konsumen, berdasarkan selera, dan berdasarkan harga, content produk, dan trend.

Tahap operasional merupakan tahap menterjemahkan konsep-konsep yang masih umum menjadi variabel, indikator dan definisi operasional.

Definisi operasional merupakan unsur penelitian tentang bagaimana cara mengukur suatu variabel, dengan kata lain definsi operasional merupakan petunjuk pelaksanaan bagaimana cara untuk mengukur variabel (Nasir,1999).

Pengukuran variabel kebudayaan, ekonomi, sosial, dan etika menggunakan skala Likert. Skala ini menggunakan pertanyaan dengan lima alternatif jawaban secara berjenjang. Jawaban dengan bobot terendah maka diberi nilai 1 (satu) dan seterusnya hingga jawaban yang berbobot tertinggi diberi nilai 5 (lima).

Jenis data menggunakan data kualitatif dan kuantitatif. Sumber data menggunakan data primer. Pengumpulan data menggunakan do- kumentasi dan kuesioner. Teknik analisis data menggunakan uji instrumen penelitian, adalah uji Chisquare.

Nilai Chi kemudian dikonsultasikan dengan tabel harga Chi Kuadrat dengan derajat kebebasan pada taraf signifikansi 95\%. Berdasarkan permasalah yang telah dikemukakan sebelumnya, maka hipotesis yang diujikan dalam penelitian ini:

Hipotesis Nihil ( Ho ) tidak ada pengaruh perilaku konsumen terhadap penggunaan situs online shop pada mahasiswa UPS Tegal. Hipotesis Kerja ( Ha ) adanya pengaruh perilaku konsumen teradap penggunaan situs online shop pada mahasiswa UPS Tegal.

\section{HASIL PENELITIAN}

Sumber data penelitian ini adalah mahasiswa sebagai pengguna internet terutama dalam mengakses situs online shop. Hasil penelusuran tidak semua mahasiwa aktif dalam mengakses situs online shop, terutama dilihat dari jenis kelamin penggunaan dalam mengakses situs on line shop. Sebagian besar di dominasi oleh mahasiswa 
berjenis kelamin perempuan yang sering mengakses situs online shop.

Berdasarkan survei sampling dihasilkan terdapat 30 responden atau $30 \%$ memiliki jenis kelamin laki-laki dan 70 responden atau $70 \%$ memiliki jenis kelamin perempuan dalam mengakses situs online shop

Hasil uji instrumen dengan menggunakan prosedur $\mathrm{X}^{2}$ Test $(U j i$ Chi Square) berdasarkan tabel silang. Dengan cara menabulasi (menyusun dalam bentuk tabel) suatu variabel dalam kategori dan menguji hipotesis bahwa frekuensi yang diobservasi (data yang diamati) tidak berbeda dari

\section{Situs Online dengan Variabel $x 1$} (kebudayaan)

\begin{tabular}{|c|c|c|c|}
\hline \multicolumn{4}{|l|}{ Chi-Square Tests } \\
\hline & Value & $\mathrm{df}$ & $\begin{array}{c}\text { Asymp. Sig. } \\
\text { (2-sided) }\end{array}$ \\
\hline Pearson Chi-Square & $142.889^{\mathrm{a}}$ & 49 & .000 \\
\hline Likelihood Ratio & 75.977 & 49 & .008 \\
\hline $\begin{array}{l}\text { Linear-by-Linear } \\
\text { Association }\end{array}$ & .124 & 1 & .724 \\
\hline N of Valid Cases & 172 & & \\
\hline
\end{tabular}

Membandingkan nilai P-value (asymp.sig) dengan tingkatan signifikansi sebesar 95\% dapat Berdasarkan pengolahan data dengan SPPS versi 17, diperoleh angka chisquare untuk variable situs online dengan variable kebudayaan (xI) sebesar 142.889 . frekuensi yang diharapkan (frekuensi teoritis). Uji goodness-of-fit dari chisquare membandingkan antara frekuensi yang diobservasi dan frekuensi yang diharapkan (expected) pada masing-masing kategori untuk menguji bahwa semua kategori mengandung proporsi nilai yang sama atau menguji bahwa masing-masing kategori mengandung proporsi nilai tertentu.uji chisquare penelitian variabel pemanfaatan teknologi informasi, budaya kerja, motivasi dan kinerja pegawai diketahui mempunyai $p$ value $<0,05$ sehingga keseluruhan item dinyatakan valid.

3. Situs online dengan variabel Sosial $* x 3$

\begin{tabular}{|c|c|c|c|}
\hline & Value & $\mathrm{df}$ & $\begin{array}{l}\text { Asymp. Sig. (2- } \\
\text { sided) }\end{array}$ \\
\hline Pearson Chi-Square & $77.440^{\mathrm{a}}$ & 35 & .000 \\
\hline Likelihood Ratio & 74.248 & 35 & .000 \\
\hline $\begin{array}{l}\text { Linear-by-Linear } \\
\text { Association }\end{array}$ & .087 & 1 & .768 \\
\hline N of Valid Cases & 172 & & \\
\hline
\end{tabular}

Pengolahan data dengan SPPS versi 17, diperoleh angka chisquare untuk variable situs online dengan variable ekonomi (x2) sebesar 148.962, dengan nilai $P$-value sebesar 0.000. dengan dikemukakan bahwa terdapat hubungan antara situs online dengan kebudayaan (asumsi frekuensi yang diharapkan terpenuhi). 
2. Situs_online dengan variabel $* x 2$ (ekonomi)

\begin{tabular}{|c|c|c|c|}
\hline \multicolumn{4}{|l|}{ Chi-Square Tests } \\
\hline & Value & $\mathrm{df}$ & $\begin{array}{c}\text { Asymp, Sig } \\
\text { (2-sided) }\end{array}$ \\
\hline Pearson Chi-Square & $148.962^{\mathrm{a}}$ & 63 & .000 \\
\hline Likelihood Ratio & 120.748 & 63 & .000 \\
\hline $\begin{array}{l}\text { Linear-by-Linear } \\
\text { Association }\end{array}$ & 12.768 & 1 & .000 \\
\hline N of Valid Cases & 172 & & \\
\hline
\end{tabular}

Pengolahan data diperoleh angka chisquare untuk variable situs online dengan variable sosial (x3) sebesar 77.440, dengan nilai P-value sebesar 0.000

\section{Situs online dengan variabel Etika* $x 4$}

Chi-Square Tests
\begin{tabular}{|l|c|c|c|}
\hline & Value & df & $\begin{array}{c}\text { Asymp. Sig. } \\
(2 \text {-sided })\end{array}$ \\
\hline Pearson Chi-Square & $57.682^{\mathrm{a}}$ & 35 & .009 \\
\hline Likelihood Ratio & 52.393 & 35 & .030 \\
\hline Linear-by-Linear & 6.606 & 1 & .010 \\
\hline Association & & & \\
\hline N of Valid Cases & 172 & & \\
\hline
\end{tabular}

a. 39 cells $(81.3 \%)$ have expected count less than 5 . The minimum expected count is 05 .

Pengolahan data diperoleh angka chisquare untuk variable situs online dengan variable etika (x4) sebesar 57.682, dengan nilai $P$-value sebesar 0.000 .

Dari perhitungan angka chisquare menggunakan SPSS keempat variable dengan variable situs online shop disajikan sebagai berikut:

Chi-Square Tests
\begin{tabular}{|l|c|c|c|}
\hline & Value & df & $\begin{array}{c}\text { Asymp. Sig. } \\
\text { (2-sided) }\end{array}$ \\
\hline Pearson Chi-Square & $148.962^{\mathrm{a}}$ & 63 & .000 \\
\hline Likelihood Ratio & 120.748 & 63 & .000 \\
\hline Linear-by-Linear & 12.768 & 1 & .000 \\
\hline Association & & & \\
\hline N of Valid Cases & 172 & & \\
\hline a. 69 cells (86.3\%) have expected count less than 5. The \\
minimum expected count is .01.
\end{tabular}

Dasar pengambilan keputusan pada penelitian ini :

Ho: tidak ada pengaruh perilaku konsumen terhadap penggunaan situs online

Ha: ada pengaruh perilaku konsumsen terhadap penggunaan situs online.

Dari output data dengan sig (2 tailed) diperoleh angka 0.000. ini berarti probabilitas kurang dari 0.05 , artinya bahwa Ho ditolak yang berarti bahwa, ada pengaruh perilaku konsumen terhadap penggunaan situs online shop.

\section{KESIMPULAN DAN SARAN}

Penelitian ini bertujuan menguji pengaruh perilaku konsumen terhadap variabel kebudayaan, ekonomi, sosial, etika dan keputusan pembelian terhadap akses situs online shop. Hasil pengujian data menunjukkan ada pengaruh perilaku 
konsumen terhadap penggunaan situs online shop.

Dari ke empat faktor tersebut ( kebudayaan, ekonomi, sosial dan etika ) yanng memiliki koefisien kontigensi paling ebsar terhadap perilaku konsumen dalam mengakses situs online shop adalah variabel Sosial. Hal ini berarti menunjukkan sekelompok masyarakat atau individu mempunyai hubungan antara konsumen satu dengan yang lainnya dalam memilih produk melalui situs online shop dan membangun komunikasi yang baik dalam memilih produk serta mengetahui resiko yang dihadapi jika membeli produk melalui situs online shop.

Berdasarkan hasil penelitian dan kesimpulan, maka penulis memberikan saran antara lain kepada :

1. Bagi Mahasiswa atau Informan diharapkan lebih bisa mengontrol perilaku pembelian produk melalui situs online shop, belajar mengatur uang sesuai dengan keinginan dan kebutuhan sehari-hari, lebih mengutamakan kebutuhan yang bisa dipenuhi.
2. Bagi orang tua, diharapkan lebih mengajarkan kepada anak tentang cara penggunaan uang dan cara mengatur uang. Tidak memanjakan dengan memberi uang berlebih selain untuk kebutuhan sehari-hari dan kebutuhan kuliah, mengajarkan untuk memilih produk apapun dengan baik.

3. Bagi peneliti selanjutnya, hasil penelitian ini dapat digunakan sebagai tambahan informasi dan bahan ajar dalam melakukan penelitian mengenai dampak perilaku konsumen terhadap penggunaan akses situs online shop di Universitas Pancasakti Tegal

\section{DAFTAR PUSTAKA}

Ambrose Jagongo, Catherine Kinyua, 2013. The Social Media and Entrepreneurship Growth. International Journal of Humanities and Social Science Vol. 3 No. 10 (Special Issue May 2013)

Bernadi, J. 2013. Aplikasi Sistem Informasi Penjualan Berbasis Web Pada Toko Velg YQ. ComTech. 4(2). Hlm. 731-741.

Diana, Anastaia. 2001, Mengenal ECommerce, Yogyakarta: Andi 
Ferdinan, AT. 2000. Manajemen Pemasaran: Sebuah Pendekatan Strategis. Badan Penerbit Undip.

Grove, J. V,2010. How Small Business Is Using Social Media [STATS], available online: http://mashable.com/2010/03/02/ small-business-stats/.

Kotler, Philip. 2001. Manajemen Pemasaran: Analisis, Perencanaan, Implementasi Dan Kontrol, Jakarta : PT. Prehallindo.

Kotler Philip dan Kevin Lane Keller 2008. Manajemen Pemarasan Jilid - 1. Jakarta: Erlangga.

Arikunto, $\quad$ Suharsimi. 2010. Manajemen Penelitian, Jakarta: Rineka Cipta.

Kotler, Phillip. 2009. Manajemen Pemasaran, Edisi 13, Jakarta: Gramedia.

Kotler, Philip dan Kevin Lane Keller. 2012. Manajemen Pemasaran. Jakarta: Erlangga.

Kwahk, K. Y., \& Ge, X. (2012). The Effects of Social Media on ECommerce: A Perspective of Social Impact Theory. 45th Hawaii International Conference on System Sciences. ISBN: 978-
0-7695-4525-7/12 (C) 2012 IEEE DOI 10.1109/ HICSS.2012.564. Hlm. 1814-1823.

Purbo, Onno W. 2000. 10 Pertanyaan Tentang E-Commerce, Mikrodata, Vol. 11 Jakarta: Pt. Elex Komputindo.

Sugiyono, 2009. Metodologi Penelitian Bisnis, Bandung: Alfabeta.

Tjiptono, Fandy dan Diana. 2007. EBusiness, Yogyakarta: Andi Offset.

Sugiyono. 2010. Statistika untuk Penelitian, Bandung: Alfabeta.

Pendidikan Metode Penelitian
Kuantitatif, Kualitatif dan
R\&D, Bandung: Alfabeta.

Sugiyono. 2014. Statistik Untuk Penelitian. Bandung: Alfabeta.

Swastha, Basu DH dan Irawan. 2008. Manajemen Pemasaran Modern. Yogyakarta: Liberty Offset.

Wibowo, Agung Edy. 2012. Aplikasi Praktis SPSS Dalam Penelitian, Yogyakarta: Gava Media 